\title{
SAMORZĄD LOKALNY A PODATEK OD TOWARÓW I USŁUG W ŚWIETLE ORZECZNICTWA TRYBUNAŁU SPRAWIEDLIWOŚCI UNII EUROPEJSKIEJ i Naczelnego Sądu Administracyjnego
}

Streszczenie. W artykule dokonano przeglądu i analizy orzecznictwa Trybunału Sprawiedliwości Unii Europejskiej i Naczelnego Sądu Administracyjnego dotyczącego opodatkowanie gmin podatkiem od towarów i usług. W praktyce stosowania prawa podatkowego, ze względu na brak precyzyjnych przepisów, gminy napotykają trudności w dokonywaniu ich interpretacji. NSA w swoich orzeczeniach stara się wypełnić powstałe luki prawne, stosując wykładnię prounijną.

Słowa kluczowe: podatek od towarów i usług, gmina jako podatnik VAT, orzecznictwo Trybunału Sprawiedliwości Unii Europejskiej, orzecznictwo Naczelnego Sądu Administracyjnego, prewspółczynnik w rozliczeniu VAT przez gminę.

\section{WPROWADZENIE}

Jednym z ważnym problemów, z którymi borykają się organy samorządu terytorialnego, jest opodatkowanie podatkiem od towarów i usług. Wynika to z niezbyt precyzyjnej legislacji podatkowej dotyczącej VAT-u, zwłaszcza w zakresie określenia podmiotów objętych tym podatkiem. Dotyczy to także sytuacji, w których organy władzy publicznej wykonują

* Doktor habilitowany nauk prawnych, prof. ALK, kierownik Zakładu Prawa Finansowego i Podatkowego, Akademia Leona Koźmińskiego, sędzia NSA, e-mail: amudrecki@ kozminski.edu.pl 
czynności urzędowe, co sprawia, że jednostka samorządu terytorialnego nie jest uznawana za podatnika. Równie trudnym zagadnieniem w interpretacji jest ustalenie zasad proporcjonalności przy rozliczeniu omawianego podatku.

Z przedstawioną problematyką spotykają się bardzo często gminy. Spory w tym zakresie rozstrzygają sądy administracyjne w Polsce. Należy także odnotować liczne wypowiedzi Trybunału Sprawiedliwości Unii Europejskiej (TSUE). Z tego względu dokonanie analizy orzecznictwa TSUE i Naczelnego Sądu Administracyjnego (NSA) może się okazać bardzo pożyteczne, odpowie bowiem na zasadnicze pytania dotyczące tego zagadnienia, które jest przedmiotem częstych wypowiedzi przedstawicieli nauki i praktyki prawa podatkowego ${ }^{1}$.

Generalnie wykładnia przepisów dotyczących podatku od towarów i usług nastręcza wielu trudności. Naczelny Sąd Administracyjny, dokonując wykładni przedmiotowych regulacji, posługuje się różnymi ich rodzajami, w tym dyrektywą językową, systemową i celowościową. Sądy administracyjne nie stronią od dokonywania wykładni prounijnej (przyjaznej prawu unijnemu) i wykładni prokonstytucyjnej (przyjaznej regulacji konstytucyjnej). NSA często podejmuje uchwały w celu ujednolicenia orzecznictwa oraz zagwarantowania pewności jego stosowania. Ważną rolę odgrywają również pytania prejudycjalne kierowane do TSUE, które mają na celu wyjaśnienie przepisów unijnych w kontekście sposobu opodatkowania gmin.

\section{GMINA JAKO PODMIOT PODATKU OD TOWARÓW I USŁUG}

Regulacje prawne w zakresie podatku od towarów i usług w praktyce ich stosowania nasuwają wiele problemów interpretacyjnych. Stosownie do aktualnej treści art. 15 ust. 1 Ustawy z dnia 11 marca 2004 r. o podatku od towarów i usług ${ }^{2}$ (dalej: u.p.t.u.) podatnikami są osoby prawne, jednostki organizacyjne niemające osobowości prawnej oraz osoby fizyczne, wykonujące samodzielnie działalność gospodarczą, o której mowa w ust. 2,

1 VAT w gminach, red. T. Bełdyga, Warszawa 2014; J. Pęczak-Czerwińska, Prewspółczynnik odliczenia VAT naliczonego, Warszawa 2016; VAT w jednostkach samorządu terytorialnego. Centralizacja wraz z pierwsza korekta prewspółczynnika, red. E. Sokołowska-Struk, Warszawa 2016; A. Bartosiewicz, Centralizacja rozliczeń VAT w samorząach. Komentarz, Warszawa 2017; A. Bieńkowska, VAT w samorządach, Warszawa 2017.

2 Tekst jedn. Dz.U. z 2018 r., poz. 2174 ze zm. 
bez względu na cel lub rezultat takiej działalności (ust. 1). Podatnikiem, o którym mowa w ust. 1, jest także jednostka organizacyjna niemająca osobowości prawnej stanowiąca przedsiębiorstwo w spadku w okresie od otwarcia spadku do dnia wygaśnięcia:

1) zarządu sukcesyjnego albo

2) uprawnienia do powołania zarządcy sukcesyjnego, jeżeli zarząd sukcesyjny nie został ustanowiony i dokonano zgłoszenia, o którym mowa w art. 12 ust. 1c ustawy z dnia 13 października 1995 r. o zasadach ewidencji i identyfikacji podatników i płatników.

Przy czym podatnika, o którym mowa wyżej, uznaje się za podatnika kontynuującego prowadzenie działalności gospodarczej zmarłego podatnika (ust. 1a).

W ust. 2 przedmiotowego artykułu na potrzeby podatku VAT zdefiniowano pojęcie działalności gospodarczej. Zgodnie z tym przepisem działalność gospodarcza obejmuje wszelką działalność producentów, handlowców lub usługodawców, w tym podmiotów pozyskujących zasoby naturalne oraz rolników, a także działalność osób wykonujących wolne zawody. Działalność gospodarcza obejmuje zwłaszcza czynności polegające na wykorzystywaniu towarów lub wartości niematerialnych i prawnych w sposób ciągły dla celów zarobkowych.

Jednym z zasadniczych sporów pomiędzy gminami a organami podatkowymi było uznanie gminy za samodzielny byt podatkowy. Organy podatkowe uznawały jednostki samorządowe i zakłady budżetowe za odrębnych podatników. Z kolei korzystniejsze dla dobrze zorganizowanych gmin było uznanie gminy za samodzielnego podatnika. $\mathrm{W}$ uchwale $\mathrm{z}$ dnia 24 czerwca 2013 r., sygn. I FPS 1/13³, NSA stanął na stanowisku, że w świetle art. 15 ust. 1 i 2 Ustawy z dnia 11 marca 2004 r. o podatku od towarów i usług ${ }^{4}$ gminne jednostki budżetowe nie są podatnikami podatku od towarów i usług.

W uzasadnieniu uchwały podkreślono, że gminna jednostka budżetowa stanowi jednostkę organizacyjną niemającą osobowości prawnej, zaliczaną do jednostek sektora finansów publicznych. Status takiej jednostki budżetowej wynika przede wszystkim z przepisów rozdziału 3 działu I Ustawy z dnia 27 sierpnia 2009 r. o finansach publicznych ${ }^{5}$,

3 ONSA i WSA 2013, nr 6, poz. 96.

4 Dz.U. z 2004 r., Nr 54, poz. 535 ze zm.

5 Dz.U. z 2009 r., Nr 157, poz. 1240 ze zm. 
w szczególności z art. 11 i 12 tego aktu. Cechą charakterystyczną gminnej jednostki budżetowej jest brak własnego mienia i dysponowanie jedynie wyodrębnioną i przekazaną w zarząd częścią majątku osoby prawnej, jaką jest gmina. W związku z tym gminna jednostka budżetowa działa jako statio municipi. O utworzeniu, połączeniu lub likwidacji gminnej jednostki budżetowej decyduje organ stanowiący jednostki samorządu terytorialnego. Rada gminy nadaje gminnej jednostce budżetowej statut, określający nazwę, siedzibę oraz przedmiot działalności. Gospodarka finansowa takiej jednostki charakteryzuje się tym, że gminna jednostka budżetowa pokrywa swoje wydatki bezpośrednio z budżetu jednostki samorządu terytorialnego, a swoje dochody odprowadza na rachunek gminy (tzw. zasada rozliczeń brutto). Powoduje to, że wielkość wydatków gminnej jednostki budżetowej nie jest w żaden sposób związana z wysokością dochodów zrealizowanych przez tę jednostkę. Ponadto gminna jednostka budżetowa nie dysponuje realizowanymi przez siebie dochodami. Natomiast organ wykonujący budżet - gmina w toku roku budżetowego - ma do dyspozycji pełną kwotę dochodów uzyskiwanych przez gminne jednostki budżetowe. W piśmiennictwie zwraca się uwagę, że ponieważ poziom wydatków ponoszonych przez taką jednostkę nie zależy od jej dochodów, nie występuje pojęcie wyniku finansowego, nie ma zatem deficytu (straty) ani nadwyżki finansowej. W związku z tym jednostki budżetowe w najpełniejszy sposób realizują funkcję redystrybucyjną, która jest podstawową funkcją finansów publicznych ${ }^{6}$.

W wyniku pytania prejudycjalnego NSA, Trybunał Sprawiedliwości Unii Europejskiej w wyroku z dnia 29 września 2015 r., sygn. C-276/14 w sprawie Gmina Wrocław przeciwko Ministrowi Finansów ${ }^{7}$, stwierdził, że art. 9 ust. 1 Dyrektywy 2006/112 w sprawie wspólnego systemu podatku od wartości dodanej należy interpretować w ten sposób, że podmioty prawa publicznego, takie jak gminne jednostki budżetowe będące przedmiotem postępowania głównego, nie mogą być uznane za podatników podatku od wartości dodanej, ponieważ nie spełniają kryterium samodzielności przewidzianego w tym przepisie. TSUE podkreślił, że posłużenie się sformułowaniami, które nie są dokładnie takie same we wszystkich wersjach językowych art. 9 ust. 1 przywołanej dyrektywy, nie podważa tego

${ }^{6}$ L. Lipiec-Warzecha, Ustawa o finansach publicznych. Komentarz, Warszawa 2011, komentarz do art. 11.

7 LEX nr 1797948. 
stwierdzenia. Zarówno bowiem sformułowanie „samodzielnie”, jak i sformułowanie „niezależnie” wskazują na potrzebę oceny podporządkowania wykonywania działalności gospodarczej (teza 36 wyroku). W niniejszej sprawie z postanowienia odsyłającego wynika, że jednostki budżetowe będące przedmiotem postępowania głównego wykonują działalność gospodarczą powierzoną im w imieniu i na rachunek Gminy Wrocław oraz że nie odpowiadają one za szkody spowodowane tą działalnością, ponieważ odpowiedzialność tę ponosi wyłącznie gmina (teza 37 wyroku). Ze wspomnianego postanowienia wynika również, że owe jednostki nie ponoszą ryzyka gospodarczego związanego z rzeczoną działalnością, ponieważ nie dysponują własnym majątkiem, nie osiągają własnych dochodów i nie ponoszą kosztów dotyczących takiej działalności, gdyż uzyskane dochody są wpłacane do budżetu Gminy Wrocław, a wydatki są pokrywane bezpośrednio $\mathrm{z}$ tego budżetu (teza 38 wyroku).

Kolejnym problemem w zakresie podmiotowości było rozstrzygnięcie, czy zakłady budżetowe są podatnikiem odrębnym od gmin, czy też to gmina jest podatnikiem, która reprezentuje także zakład budżetowy. Naczelny Sąd Administracyjny w przełomowej uchwale z dnia 26 października 2015 r., sygn. I FPS $4 / 15^{8}$, uznał, że to gmina, a nie samorządowy zakład budżetowy jest samodzielnym podatnikiem podatku od towarów i usług. W sentencji uchwały przyjęto, że w świetle art. 15 ust. 1 oraz art. 86 ust. 1 Ustawy z dnia 11 marca 2004 r. o podatku od towarów i usług gmina ma prawo do odliczenia podatku naliczonego z faktur zakupowych związanych $\mathrm{z}$ realizacją inwestycji, które zostały następnie przekazane do gminnego zakładu budżetowego, realizującego powierzone mu zadania własne tej gminy, jeżeli inwestycje są wykorzystywane do sprzedaży opodatkowanej podatkiem od towarów i usług.

W uzasadnieniu uchwały NSA doszedł do wniosku, że:

1) samorządowy zakład budżetowy nie ma osobowości prawnej - działa w imieniu i na rachunek podmiotu, który go utworzył, a kierownik zakładu działa jednoosobowo na podstawie udzielonego pełnomocnictwa;

2) samorządowy zakład budżetowy realizuje tylko zadania własne jednostki samorządu terytorialnego w zakresie gospodarki komunalnej o charakterze czynności użyteczności publicznej;

8 „Przegląd Orzecznictwa Podatkowego” 2015, nr 6, s. 577-584.

9 Dz.U. z 2011 r., Nr 177, poz. 1054 ze zm. 
3) wydzielenie mienia na rzecz samorządowego zakładu budżetowego ma jedynie charakter organizacyjny; mienie pozostaje w bezpośrednim władztwie jednostki samorządu terytorialnego, która określa zasady gospodarowania mieniem wydzielonym na potrzeby zakładu;

4) odpowiedzialność za zobowiązania samorządowego zakładu budżetowego ponosi jednostka samorządu terytorialnego, która go utworzyła; jednostka samorządu terytorialnego przejmuje również zobowiązania zakładu budżetowego w przypadku jego likwidacji.

W świetle kryteriów samodzielności podatnika wskazanych w wyroku TSUE z dnia 29 września 2015 r. w sprawie C-276/14 Gmina Wrocław nie można więc uznać, że samorządowy zakład budżetowy wykonuje działalność gospodarczą we własnym imieniu, na własny rachunek i na własną odpowiedzialność. Nie ponosi on związanego z prowadzeniem działalności gospodarczej ryzyka gospodarczego. Trybunał w wyroku tym jednoznacznie wskazał bowiem, że dla oceny samodzielności podmiotu jako podatnika VAT za istotne uznać należy, czy dana osoba wykonuje działalność we własnym imieniu, na własny rachunek i na własną odpowiedzialność oraz czy ponosi związane z prowadzeniem działalności ryzyko gospodarcze. Wprawdzie samorządowy zakład budżetowy ma większą samodzielność niż jednostka budżetowa, na tle której to właściwości wypowiadał się TSUE, lecz ze względu na niespełnianie powyższych warunków nie można stwierdzić, że ma on podmiotowość podatkową VAT odrębną od jednostki samorządu terytorialnego, która go utworzyła.

Podsumowując, stwierdzić można, że o braku wystarczającej samodzielności zakładu budżetowego w rozważanym kontekście świadczy jego istota. Należy bowiem uwzględnić, że samorządowy zakład budżetowy powoływany jest do wykonywania zadań własnych jednostki samorządu terytorialnego w przedmiocie gospodarki komunalnej, działając w tym zakresie w jej imieniu, jako jej wyodrębniona jednostka organizacyjna, opierając się na oddanym w trwały zarząd majątku gminy. Oznacza to, że majątek ten pozostaje w dalszym ciągu własnością tej jednostki i wykorzystywany jest do realizacji jej ustawowych zadań, lecz ze względów pragmatycznych - za pośrednictwem tegoż zakładu ${ }^{10}$.

10 A. Mudrecki, VAT in the Polish Commune, [w:] The Financial Law Towards Challenges of the XXI Century, red. M. Radvan, J. Gliniecka, T. Sowiński, P. Mrkyvka, Brno 2017, s. 327. 
3. ZMIANY LEGISLACYJNE WPROWADZONE W ZWIĄZKU Z WYROKIEM

TrybunaŁu Sprawiedliwości UniI EuropejSKiej Z DNIA 29 WRZEŚNIA 2015 R., SYGN. C-276/14, ORAZ ORZECZNICTWEM NSA

Należy pozytywnie ocenić, że prawodawca postanowił w celu realizacji omawianego wyroku TSUE dokonać zmian legislacyjnych i doprowadzić do opodatkowania gminy jako jednego podmiotu. Z dniem 1 stycznia 2016 r. wszedł w życie pakiet zmian wprowadzanych Ustawą z dnia 9 kwietnia 2015 r. o zmianie ustawy o podatku od towarów i usług oraz ustawy - Prawo zamówień publicznych ${ }^{11}$. W szczególności zmienione zostały przepisy dotyczące sposobu obliczania współczynnika proporcji odliczenia VAT naliczonego. Pozytywnie należy ocenić wydanie 17 lutego 2016 r. przez Ministerstwo Finansów Broszury informacyjnej w sprawie zasad odliczania podatku od towarów i usług przez podatników prowadzących działalność o charakterze mieszanym. Szerszym wyjaśnieniem kwestii wątpliwych $\mathrm{w}$ związku $\mathrm{z}$ wejściem $\mathrm{w}$ życie przywołanej ustawy zajęła się J. Pęczak-Czerwińska w monografii Prewspółczynnik odliczenia VAT naliczonego ${ }^{12}$.

Nie była to jednak ostatnia nowelizacja przepisów w tym zakresie. Z dniem 1 października 2016 r. weszła w życie Ustawa z dnia 5 września 2016 r. o szczególnych zasadach rozliczeń podatku od towarów i usług oraz dokonywania zwrotu środków publicznych przeznaczonych na realizację projektów finansowanych $\mathrm{z}$ udziałem środków pochodzących z budżetu Unii Europejskiej lub od państw członkowskich Europejskiego Porozumienia o Wolnym Handlu przez jednostki samorządu terytorialnego ${ }^{13}$.

W akcie tym określono zasady dokonywania rozliczeń podatku przez jednostki samorządu terytorialnego od dnia 1 stycznia 2017 r. (rozdział 2). W rozdziale 3 wskazano na zasady dokonywania przez jednostki samorządu terytorialnego korekt rozliczeń podatku za okresy rozliczeniowe upływające przed dniem podjęcia przez nie rozliczania podatku wraz ze wszystkimi jednostkami organizacyjnymi. Poruszono problematykę dokonywania w określonych sytuacjach przez jednostki samorządu terytorialnego zwrotu środków przeznaczonych na realizację projektów w przypadku zmiany kwalifikowalności podatku w związku z wyrokiem TSUE (rozdział 4).

11 Dz.U. z 2015 r., poz. 605.

12 J. Pęczak-Czerwińska, Prewspółczynnik..., s. 257.

13 Dz.U. z 2016 r., poz. 1454. 
Regulacje prawne zawarte $\mathrm{w}$ analizowanym akcie prawnym należy zaliczyć do skomplikowanych, mogących w praktyce wywoływać sporo kontrowersji. Poza tym nakładają one na organy samorządu terytorialnego liczne obowiązki, z którymi mniejsze gminy lub większe, ale gorzej zorganizowane, mogą sobie nie poradzić. Również i w tym wypadku należy pozytywnie ocenić Broszurę Ministerstwa Finansów z dnia 24 listopada 2016 r. w sprawie centralizacji rozliczeń w podatku VAT jednostek samorządu terytorialnego. Wskazany dokument jest napisany przystępnym językiem i wyjaśnia wiele zawiłości prawnych, co jednak nie gwarantuje, że stosowanie przyjętych regulacji prawnych nie będzie wywoływało sporów sądowych ${ }^{14}$.

W praktyce stosowania prawa podatkowego powstał problem, czy gmina, dokonując korekty deklaracji podatkowej, powinna uwzględnić wszystkie podległe jednostki, czy też może ograniczyć się do wybranych. W tej sprawie wypowiedział się NSA w wyroku z dnia 23 kwietnia 2018 r. $^{15}$, sygn. I FSK 1237/17, w którym wskazał, że dla skuteczności złożonej przez jednostkę samorządu terytorialnego przed dniem 1 października 2016 r. deklaracji korygującej rozliczenie w zakresie podatku od towarów i usług w związku z wyrokiem TSUE z dnia 29 września 2015 r. w sprawie C-276/14 Gmina Wrocław przeciwko Ministrowi Finansów, tj. w celu realizacji uprawnienia $\mathrm{z}$ art. 86 ust. 1 Ustawy $\mathrm{z}$ dnia 11 marca 2004 r. o podatku od towarów i usług, wymagana jest w świetle art. 23 w zw. z art. 12 Ustawy z dnia 5 września 2016 r. o szczególnych zasadach rozliczeń podatku od towarów i usług centralizacja rozliczeń jednostki samorządu terytorialnego i wszystkich jej niesamodzielnych jednostek organizacyjnych, począwszy od najwcześniejszego okresu rozliczeniowego, którego dotyczy korekta.

4. ROZLICZENIE PODATKU PRZEZ GMINĘ PRZY CZYNNOŚCIACH NIEPODLEGAJĄCYCH OPODATKOWANIU

Jednym $\mathrm{z}$ istotnych zagadnień związanych z możliwością liczenia proporcji przy opodatkowaniu, gdy występują czynności niepodlegające opodatkowaniu, zajął się NSA w uchwale z dnia 24 października 2011 r., sygn. I FPS $9 / 10^{16}$. W orzeczeniu tym wskazano, że w świetle przepisów

14 A. Mudrecki, VAT..., s. 328-329.

15 http://orzeczenia.nsa.gov.pl/doc/5BD7E4AC82

16 http://orzeczenia.nsa.gov.pl/doc/15320108B2 
art. 86 ust. 1 oraz art. 90 ust. 1 i 2 Ustawy z dnia 11 marca 2004 r. o podatku od towarów i usług czynności niepodlegające opodatkowaniu podatkiem od towarów i usług nie mogą wpłynąć na zakres prawa do odliczenia podatku naliczonego przy zastosowaniu art. 90 ust. 3 powołanej wyżej ustawy.

Od tego poglądu w wyniku pytania prejudycjalnego odstąpił TSUE w wyroku z dnia 8 maja 2019 r., sygn. C 566/17 ${ }^{17}$. W ocenie Trybunału art. 168 lit. a Dyrektywy Rady 2006/112/WE z dnia 28 listopada 2006 r. w sprawie wspólnego systemu podatku od wartości dodanej należy interpretować w ten sposób, że sprzeciwia się on praktyce krajowej zezwalającej podatnikowi na pełne odliczenie podatku od wartości dodanej (VAT) naliczonego w związku z nabyciem przez niego towarów i usług w celu prowadzenia zarówno działalności gospodarczej, opodatkowanej VAT, jak i działalności niemającej charakteru gospodarczego, która nie wchodzi w zakres stosowania VAT, ze względu na brak we właściwych przepisach podatkowych szczególnych uregulowań dotyczących kryteriów i metod podziału, umożliwiających podatnikowi określenie części tego VAT naliczonego, którą należy uważać za związaną, odpowiednio, z jego działalnością gospodarczą i z działalnością niemającą charakteru gospodarczego.

Konsekwencją cytowanego wyroku były orzeczenia Naczelnego Sądu Administracyjnego. W precedensowym wyroku z dnia 2 lipca 2019 r., sygn. I FSK $119 / 17^{18}$, NSA uznał, że przepis art. 86 ust. 1 Ustawy z dnia 11 marca 2004 r. o podatku od towarów i usług należy - w świetle wyroku TSUE z dnia 8 maja 2019 r. w sprawie C-566/17 Związku Gmin Zagłębia Miedziowego w Polkowicach - rozumieć w ten sposób, że brak w stanie prawnym obowiązującym do 31 grudnia 2015 r. w przywołanej ustawie uregulowań dotyczących kryteriów i metod podziału, które umożliwiłyby podatnikowi określenie podlegającej odliczeniu części naliczonego podatku od towarów i usług związanego z jego działalnością gospodarczą i z działalnością niemającą charakteru gospodarczego, nie dawał podatnikowi podstawy do pełnego odliczenia tego podatku.

17 http://www.nsa.gov.pl/komunikaty/wyrok-trybunalu-sprawiedliwosci-z-dnia-8maja-2019-r-w-sprawie-c-566-17-zwiazek-gmin-zaglebia-miedziowego-w-polkowicachprzeciwko-szefowi-krajowej-administracji-skarbowej,news,4,637.php?p=2

18 http://www.orzeczenia-nsa.pl/wyrok/i-fsk-119-17/podatek_od_towarow_i_ uslug/22ab9e1.html 
Wyrażone w art. 2 Konstytucji RP zasady demokratycznego państwa prawa oraz pewności prawa sprzeciwiają się temu, aby w przypadku okresów rozliczeniowych sprzed 1 stycznia 2016 r. podatnicy, którzy ze względu na brak w stanie prawnym obowiązującym do 31 grudnia 2015 r. w u.p.t.u. uregulowań dotyczących kryteriów i metod podziału umożliwiających podatnikowi określenie podlegającej odliczeniu części naliczonego podatku od towarów i usług związanego z jego działalnością gospodarczą i z działalnością niemającą charakteru gospodarczego, dokonali pełnego odliczenia tego podatku zgodnie $\mathrm{z}$ wykładnią prawa wyrażoną przez NSA w uchwale 7 sędziów z dnia 24 października 2011 r., sygn. I FPS 9/10, ponosili tego konsekwencje i byli - ze względu na zmianę wykładni art. 86 ust. 1 u.p.t.u. w sposób określony w punkcie 1 - zobligowani do korekty rozliczeń tych okresów rozliczeniowych, co do których zobowiązania podatkowe nie uległy przedawnieniu.

Powyższy wyrok należy ocenić pozytywnie. Z jednej strony NSA uznał rozstrzygnięcie TSUE, a z drugiej - ze względu na konieczność przestrzegania zasad konstytucyjnych, tj. demokratycznego państwa prawa i pewności co do prawa - ograniczono zasięg stosowania rozstrzygnięcia TSUE.

Pewne zastrzeżenia budzi forma rozstrzygnięcia. W mojej ocenie $\mathrm{w}$ pierwszej kolejności skład rozpoznający sprawę powinien $\mathrm{w}$ trybie art. $269 \$ 1$ Ustawy z dnia 30 sierpnia 2002 r. - Prawo o postępowaniu przed sądami administracyjnymi ${ }^{19}$ wyeliminować moc wiążącą uchwały NSA z dnia 24 października 2011 r., sygn. I FPS 9/10. Stosownie do treści tego przepisu, jeżeli jakikolwiek skład sądu administracyjnego rozpoznający sprawę nie podziela stanowiska zajętego w uchwale składu 7 sędziów, całej Izby albo w uchwale pełnego składu Naczelnego Sądu Administracyjnego, przedstawia powstałe zagadnienie prawne do rozstrzygnięcia odpowiedniemu składowi. W takim wypadku skład rozszerzony NSA nie może odmówić udzielenia odpowiedzi. W sytuacji gdy istnieje procedura dająca możliwość dostosowania wykładni prawa do wykładni prounijnej wynikającej z autonomii prawa procesowego państw członkowskich, powinno się wykorzystać taką procedurę. Cytowany przepis jest jednoznaczny i nie powinien być pomijany.

19 Tekst jedn. Dz.U. z 2018 r., poz. 1302 ze zm. 


\section{PRAWO DO ODLICZENIA PODATKU NALICZONEGO PRZY ZMIANIE}

Wiele inwestycji gmin było przeznaczonych na zaspokojenie potrzeb mieszkańców w ramach zadań własnych samorządu terytorialnego. W związku z tym nie przysługiwało im prawo do odliczenia podatku naliczonego. W tej kwestii dosyć śmiałe orzeczenie zmieniające dotychczasową praktykę wydał Trybunał Sprawiedliwości Unii Europejskiej. W wyroku z dnia 25 lipca 2018 r., sygn. C-140/1720, TSUE wskazał, że artykuły 167, 168 i 184 Dyrektywy Rady 2006/112/WE z dnia 28 listopada 2006 r. w sprawie wspólnego systemu podatku od wartości dodanej oraz zasadę neutralności podatku od wartości dodanej (VAT) należy interpretować w ten sposób, że nie stoją one na przeszkodzie temu, aby podmiot prawa publicznego korzystał z prawa do korekty odliczenia VAT zapłaconego od dobra inwestycyjnego stanowiącego nieruchomość w sytuacji takiej jak rozpatrywana w postępowaniu głównym, gdy w chwili nabycia tego dobra z jednej strony, ze względu na swój charakter, mogło ono być wykorzystywane zarówno do celów czynności opodatkowanych, jak i nieopodatkowanych, ale w początkowym okresie było wykorzystywane na cele działalności nieopodatkowanej, a z drugiej strony ten podmiot prawa publicznego nie wskazał wyraźnie zamiaru wykorzystywania tego dobra do celów działalności opodatkowanej, lecz także nie wykluczył, że będzie ono wykorzystywane do takich celów, o ile z analizy wszystkich okoliczności faktycznych, której przeprowadzenie należy do sądu krajowego, wynika, że został spełniony warunek ustanowiony w art. 168 dyrektywy 2006/112, zgodnie z którym podatnik powinien działać w takim charakterze w momencie, w którym dokonał nabycia.

Cytowane rozstrzygnięcie dawało możliwość złożenia korekty deklaracji i żądania zwrotu nadpłaty. W każdej jednak sprawie do sądu krajowego należy ocena, czy gminie przysługuje, przy zmianie przeznaczenia inwestycji, prawo do zwrotu nadpłaty.

Bardzo często złożenie wniosku o zwrot nadpłaty wraz z korektą deklaracji następuje po upływie czasu dającego prawo do zwrotu, tj. w okresie przedawnienia. W tym wypadku TSUE uznał, że upływ okresu przedawnienia ogranicza prawo do zwrotu nadpłaty. W wyroku z dnia 20 grudnia 2017 r., sygn. C-500/16²1, Trybunał przyjął, że zasady równo-

${ }^{20}$ http://www.nsa.gov.pl/pytania-prejudycjalne-wsa-i-nsa.php

${ }^{21}$ http://www.nsa.gov.pl/komunikaty/wyrok-trybunalu-z-dnia-20-grudnia-2017-r -w-sprawie-c-500-16-caterpillar-financial-services-sp-z-o-o,news, 4,508.php? $\mathrm{p}=5$ 
ważności i skuteczności należy w świetle art. 4 ust. 3 TUE ${ }^{22}$ interpretować w ten sposób, że nie stoją one na przeszkodzie przepisom krajowym tego rodzaju, co przepisy w postępowaniu głównym, umożliwiającym oddalenie wniosku o zwrot nadpłaty podatku od wartości dodanej (VAT), gdy wniosek ów został złożony przez podatnika po upływie pięcioletniego terminu przedawnienia, pomimo że z wyroku Trybunału wydanego po upływie owego terminu wynika, że zapłata VAT stanowiąca przedmiot owego wniosku o zwrot nie była należna.

\section{CZYNNOŚCI WYKONYWANE PRZEZ GMINĘ NIEOBJĘTE PODATKIEM OD TOWARÓW I USŁUG NA TLE ORZECZNICTWA NSA}

Opodatkowanie gmin podatkiem od towarów i usług wywołuje wiele trudności wynikających z niezbyt precyzyjnego rozdzielenia zadań jednostek samorządu terytorialnego wykonywanych w ramach władztwa administracyjnego lub jako umowy cywilnoprawne ${ }^{23}$.

Najwięcej kontrowersji w zakresie wykładni przepisów prawa dotyczy art. 15 ust. 6 u.p.t.u. Zgodnie z tym przepisem nie uznaje się za podatnika organów władzy publicznej oraz urzędów obsługujących te organy w zakresie realizowanych zadań nałożonych odrębnymi przepisami prawa, dla realizacji których zostały one powołane, z wyłączeniem czynności wykonywanych na podstawie zawartych umów cywilnoprawnych.

Wyłączenie z definicji podatnika podatku od towarów i usług jednostek organów samorządowych ma charakter podmiotowo-przedmiotowy i ze względu na zasadę powszechności opodatkowania przepis ten powinien być interpretowany ściśle. To zatem charakter wykonywanych czynności będzie przesądzał, czy gmina jest podatnikiem podatku od towarów i usług czy też nie. Gdy gmina wykonuje czynności o charakterze publicznoprawnym, nie jest podatnikiem analizowanego podatku, ale gdy wykonuje czynności cywilnoprawne, to wówczas staje się podatnikiem podatku od towarów i usług ${ }^{24}$.

22 https://eur-lex.europa.eu/resource.html?uri=cellar:9e8d52e1-2c70-11e6-b49701aa75ed71a1.0018.01/DOC_2\&format=PDF

23 A. Mudrecki, Rozdział IV. Gmina jako podatnik podatku od towarów i usług w świetle orzecznictwa Trybunału Sprawiedliwości Unii Europejskiej, [w:] Finansowanie zadań publicznych służących zaspokojeniu potrzeb wspólnot samorządowych, red. A. Zalcewicz, Warszawa 2016, s. 236.

24 J. Zubrzycki, Leksykon VAT 2011, t. 1, Wrocław 2011, s. 470. 
W wyroku z dnia 9 czerwca 2017 r., sygn. I FSK 1271/15 25, NSA uznał, że stosownie do art. 15 ust. 6 Ustawy z dnia 11 marca 2004 r. o podatku od towarów i usług gmina nie będzie podatnikiem podatku VAT, realizując zadania w zakresie edukacji w postaci organizacji: stołówek szkolnych, wypoczynku dzieci i młodzieży, uczestnictwa dzieci i młodzieży w widowiskach artystycznych i nauce pływania oraz uczestnictwa dzieci i młodzieży w wymianie międzynarodowej. W uzasadnieniu wyroku powołano się na wykładnię systemową zewnętrzną, w której odwołano się do regulacji związanych z samorządem gminnym i prawem oświatowym. Poza tym zastosowano wykładnię prounijną, zwracając uwagę, że opłaty za stołówki szkolne nie miały charakteru komercyjnego. Wreszcie powołano się na zasadę in dubio pro tributario wynikającą z art. 2a Ustawy z dnia 29 sierpnia 1997 r. Ordynacja podatkowa ${ }^{26}$, dostrzegając mało precyzyjną regulację art. 15 ust. 6 u.p.t.u.

Podobne orzeczenie zapadło w wyroku NSA z dnia 9 czerwca 2017 r., sygn. I FSK 1317/15 ${ }^{27}$. Przyjęto w nim, że zapewnienie wyżywienia dzieciom w przedszkolu mieści się w zadaniach edukacyjnych gminy wykonywanych jako organ władzy publicznej i w związku z tym w analizowanym tu zakresie gmina nie jest podatnikiem podatku VAT, stosownie do art. 15 ust. 6 u.p.t.u. Świadczenie pobytu i nauczania w przedszkolu po godzinie 13.00 nie ma charakteru komercyjnego. Opłaty za takie świadczenie ustala rada gminy.

W kolejnym wyroku z dnia 8 grudnia 2015 r., sygn. I FSK 1192/14 ${ }^{28}$, NSA uznał, że w świetle regulacji u.p.t.u. oraz ustawy o utrzymaniu czystości i porządku w gminach gmina, ustalając stawkę opłaty za gospodarowanie odpadami komunalnymi (w tym budowlanymi) i pobierając ją od właścicieli nieruchomości, występować będzie w pozycji nadrzędnej w stosunku do podmiotów uczestniczących w danej czynności (właścicieli nieruchomości), wykonując zadania $\mathrm{z}$ zakresu władzy publicznej określone w przepisach ustawy o samorządzie gminnym. Z powyższego wynika zatem, że gmina $\mathrm{z}$ tytułu realizacji „zadania dodatkowego”, tj. wskazanego we wniosku o wydanie interpretacji „świadczenia usługi odbierania odpadów komunalnych od właścicieli nieruchomości i zagospodarowania odpa-

25 http://www.orzeczenia-nsa.pl/wyrok/i-fsk-1271-15/podatek_od_towarow_i_ uslug/cd80e8.html

26 Tekst jedn. Dz.U. z 2019 r., poz. 900 ze zm.

27 http://orzeczenia.nsa.gov.pl/doc/705CFA4C16

${ }^{28}$ LEX nr 1932086. 
dów w postaci podstawienia oraz odbioru kontenerów przeznaczonych na odpady budowlane", będzie wyłączona $\mathrm{z}$ opodatkowania, gdyż realizuje te zadania jako zadania własne na podstawie reżimu publicznoprawnego.

W wyroku z dnia 26 marca 2015 r., sygn. I FSK 472/14 ${ }^{29}$, NSA przyjął, że regulowanie zasad korzystania z przystanków komunikacyjnych lub dworców należy do sfery władztwa publicznego, w które wyposażono gminę w celu zaspokajania potrzeb wspólnoty. Stronami tego stosunku są bowiem: gmina, która działa w charakterze organu władzy publicznej, oraz podmiot, któremu przepisy prawa umożliwiają korzystanie z mienia komunalnego $\mathrm{w}$ ramach zasad określonych $\mathrm{w}$ przepisach regulujących organizację publicznego transportu zbiorowego. Ponadto tryb ustalania wysokości opłaty wskazuje, że mamy tu do czynienia z opłatą zbliżoną do daniny publicznej, a nie z ceną ustalaną w realiach rynkowych. Stosunek prawny łączący gminę oraz podmioty korzystające $z$ jej mienia komunalnego powstaje $\mathrm{w}$ dominującym stopniu na podstawie administracyjnoprawnej metody regulacji, która na plan dalszy spycha cywilnoprawny charakter zawieranych umów. Strony tego stosunku nie mają bowiem pełnej swobody co do ustalania jego treści, albowiem ograniczają je przepisy powszechnie obowiązującego prawa administracyjnego. Zgodnie z art. 15 ust. 6 u.p.t.u. nie uznaje się za podatnika organów władzy publicznej oraz urzędów obsługujących te organy w zakresie realizowanych zadań nałożonych odrębnymi przepisami prawa, dla realizacji których zostały one powołane, $\mathrm{z}$ wyłączeniem czynności wykonywanych na podstawie zawartych umów cywilnoprawnych.

Z kolei w wyroku Wojewódzkiego Sądu Administracyjnego we Wrocławiu z dnia 27 sierpnia 2014 r., sygn. I SA/Wr 1581/14³0, przyjęto, że również gmina, która przekazuje odpłatnie pojazdy do demontażu, nie jest podatnikiem VAT, ponieważ nie prowadzi działalności gospodarczej w tym zakresie.

W orzeczeniu z dnia 10 lipca 2007 r., sygn. I FSK 924/06², NSA zaakcentował, że pobór i wpłata opłaty targowej, która jest świadczeniem o charakterze publicznoprawnym (art. $2 \$ 1$ pkt 1 Ordynacji podatkowej), przez inkasenta nie jest świadczeniem usługi w rozumieniu art. 2 ust. 1 ustawy z 1993 r. o podatku od towarów i usług oraz o podatku akcyzowym.

\footnotetext{
${ }^{29}$ LEX nr 1659176.

30 LEX nr 1506447.

31 LEX nr 416773.
} 
W orzecznictwie Naczelnego Sądu Administracyjnego wykształciła się jednolita linia orzecznictwa dotycząca braku możliwości opodatkowania świadczonych przez gminę usług w zakresie pomocy społecznej. W wyroku z dnia 23 marca 2017 r., sygn. I FSK 1147/15 32, NSA stanął na stanowisku, że zgodnie z przepisami - art. 15 ust. 6 u.p.t.u. - nie uznaje się za podatnika organów władzy publicznej oraz urzędów obsługujących te organy w zakresie realizowanych zadań nałożonych odrębnymi przepisami prawa, dla realizacji których zostały one powołane, z wyłączeniem czynności wykonywanych na podstawie zawartych umów cywilnoprawnych. Przepis ten wykładany literalnie uzależnia podmiotowość organu w podatku od towarów i usług od charakteru stosunku prawnego, w ramach którego świadczenie jest dokonywane. Świadczenia w ramach stosunków administracyjnoprawnych (publicznoprawnych) pozostają tym samym poza sferą opodatkowania podatkiem od towarów i usług. Wyłączenie z opodatkowania podatkiem od towarów i usług w trybie art. 15 ust. 6 u.p.t.u. dotyczy tylko tych czynności, które są bezpośrednią realizacją zadań publicznych (np. załatwiania indywidualnych spraw w trybie administracyjnym, pobierania należności publicznoprawnych). Nie dotyczy natomiast wszelkich innych transakcji jedynie pośrednio związanych z realizacją zadań publicznych. Fakt, że realizacja tego typu czynności następuje w trybie przepisów należących do sfery prawa publicznego i kosztem funduszy publicznych, nie może mieć istotnego znaczenia dla stosowania art. 15 ust. 6 u.p.t.u. Ośrodek pomocy społecznej nie musi rejestrować w kasie fiskalnej opłat pobieranych za pobyt w mieszkaniach readaptacyjnych.

W wyroku z dnia 12 sierpnia 2015 r., sygn. I FSK 943/14³, NSA przyjął, że wydatki związane z promocją miasta i utrzymaniem zieleni należą do zadań własnych gminy. Ponadto poczynione przez gminę wydatki o charakterze promocyjnym, jak i wydatki dotyczące pielęgnacji zieleni, utrzymania czystości oraz budowy, utrzymania i remontu chodników oraz kosztów ponoszonych w związku z wytworzeniem i utrzymaniem infrastruktury oświetleniowej są wydatkami ponoszonymi w ramach zadań własnych gminy.

Można jednak wskazać wiele czynności, w przypadku których organ władzy publicznej, w tym miasto na prawach powiatu, uznawany jest za podatnika.

32 http://orzeczenia.nsa.gov.pl/doc/56577259D0

33 „Przegląd Orzecznictwa Podatkowego” 2016, nr 1, s. 45-47. 
W wyroku z dnia 13 czerwca 2018 r., sygn. C-665/1734, TSUE rozstrzygnął wieloletni spór w zakresie opodatkowania wywłaszczenia gruntów gminy na prawach powiatu na rzecz Skarbu Państwa. W orzeczeniu tym wskazano, że art. 2 ust. 1 lit. a oraz art. 14 ust. 2 lit. a Dyrektywy Rady 2006/112/WE z dnia 28 listopada 2006 r. w sprawie wspólnego systemu podatku od wartości dodanej należy interpretować w ten sposób, że transakcję podlegającą opodatkowaniu podatkiem od wartości dodanej stanowi przeniesienie własności nieruchomości należącej do podatnika podatku od wartości dodanej na rzecz Skarbu Państwa, państwa członkowskiego, dokonane $\mathrm{z}$ mocy prawa i w zamian za zapłatę odszkodowania, w sytuacji takiej jak rozpatrywana w postępowaniu głównym, w której ta sama osoba reprezentuje zarazem organ wywłaszczający i wywłaszczaną gminę i w której ta ostatnia nadal w praktyce zarządza daną nieruchomością, nawet jeżeli wypłata odszkodowania została dokonana tylko jako wewnętrzne przeksięgowanie w budżecie gminy.

\section{Podsumowanie}

Opodatkowanie gmin podatkiem od towarów i usług jest bardzo aktualnym problemem, z którym borykają się jednostki samorządu terytorialnego. Trudności $\mathrm{w}$ interpretacji przepisów prawa podatkowego $\mathrm{w}$ zakresie określenia opodatkowania podatkiem VAT gmin wynikają z mało precyzyjnych przepisów. W związku z tym należy podjąć pilne działania legislacyjne zmierzające do uchwalenia klarownych rozwiązań prawnych z zachowaniem techniki prawodawczej i z uwzględnieniem dotychczasowego dorobku orzeczniczego NSA i TSUE.

$\mathrm{Z}$ analizy orzecznictwa Naczelnego Sądu Administracyjnego i Trybunału Sprawiedliwości Unii Europejskiej wynika, że gminne jednostki budżetowe i gminne zakłady budżetowe nie są samodzielnymi podatnikami podatku od towarów i usług. Takim podatnikiem jest bowiem gmina. Przyjęta wykładnia przepisów prawa pozwoliła gminom poprzez korekty deklaracji odzyskać podatek od towarów i usług.

Rozwiązania prawne będące konsekwencją orzecznictwa TSUE i NSA, pozwalające na centralizację rozliczeń gminy i możliwość składania korekty deklaracji oraz rozwiązujące problem zwrotu środków unijnych, porządkują zaistniałą sytuację. Brak jednak jasnych przepisów pozwalających na

${ }^{34}$ www.nsa.gov.pl 
oddzielenie czynności gminy wykonywanych jako organ władzy publicznej od czynności opodatkowanych podatkiem od towarów i usług.

$\mathrm{Z}$ analizy orzecznictwa NSA w zakresie wykładni art. 15 ust. 6 u.p.t.u. wynika, że orzeczenia mają charakter kazuistyczny i nie można uznać, iż sądy administracyjne przy wykładni przepisów prawa stosują określoną strategię.

\section{BIBLIOGRAFIA}

Bartosiewicz A., Centralizacja rozliczeń VAT w samorządach. Komentarz, Warszawa 2017. Bartosiewicz A., Kubacki R., VAT, Komentarz LEX, 2012.

Bieńkowska A., VAT w samorzadach, Warszawa 2017.

Lipiec-Warzecha L., Ustawa o finansach publicznych. Komentarz, Warszawa 2011.

Mudrecki A., Rozdział IV. Gmina jako podatnik podatku od towarów i usług w świetle orzecznictwa Trybunału Sprawiedliwości Unii Europejskiej, [w:] Finansowanie zadań publicznych stużacych zaspokojeniu potrzeb wspólnot samorządowych, red. A. Zalcewicz, Warszawa 2016.

Mudrecki A., VAT in the Polish Commune, [w:] The Financial Law Towards Challenges of the XXI Century, red. M. Radvan, J. Gliniecka, T. Sowiński, P. Mrkyvka, Brno 2017.

Pęczak-Czerwińska J., Prewspótczynnik odliczenia VAT naliczonego, Warszawa 2016.

VAT w gminach, red. T. Bełdyga, Warszawa 2014.

VAT $w$ jednostkach samorzadu terytorialnego. Centralizacja wraz z pierwsza korekta prewspółczynnika, red. E. Sokołowska-Struk, Warszawa 2016.

Zubrzycki J., Leksykon VAT 2011, t. 1, Wrocław 2011.

\section{LOCAL AUTHORITIES AND VALUE ADDED TAX IN THE LIGHT of the Case LaW of THE Court of Justice of the European Union and the Supreme Administrative Court}

Summary. The article reviews and analyses the jurisprudence of the Court of Justice of the European Union and the Supreme Administrative Court concerning the taxation of municipalities with the tax on goods and services. In the practice of application of the tax law, due to the lack of precise regulations, municipalities encounter difficulties in interpreting them. The Supreme Administrative Court in its rulings tries to fill the gaps in the law by applying a pro-EU interpretation.

Keywords: value added tax, municipality as a VAT taxpayer, case law of the Court of Justice of the European Union, case law of the Supreme Administrative Court, pre-factor in the settlement of VAT by the municipality. 